\title{
Assessment of soil fertility status of Agriculture Research Station, Belachapi, Dhanusha, Nepal
}

${ }^{1}$ Dinesh Khadka*, ${ }^{1}$ Sushil Lamichhane, ${ }^{2}$ Shahabuddin Khan, ${ }^{1}$ Sushila Joshi and ${ }^{1}$ Buddhi Bahadur Pant

${ }^{1}$ Soil Science Division, NARC, Khumaltar, Lalitpur, Nepal

${ }^{2}$ Agriculture Research Station, NARC, Belachapi, Dhanusha, Nepal

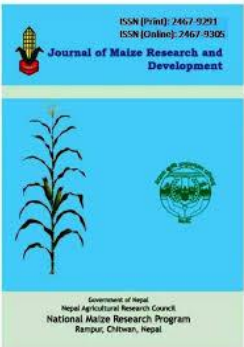

*Corresponding author email: dinesh.khadka92@gmail.com

Received: September 2016; Revised: October 2016; Accepted: November 2016

\begin{abstract}
Soil test-based fertility management is important for sustainable soil management. This study was carried out to determine the soil fertility status of the Agriculture Research Station, Belachapi, Dhanusha, Nepal. Using soil sampling auger 25 soil samples were collected randomly from a depth of $0-20 \mathrm{~cm}$. Soil sampling points were identified using GPS device. Following standard methods adopted by Soil Science Division laboratory, Khumaltar, the collected soil samples were analyzed to find out their texture, $\mathrm{pH}, \mathrm{N}$, $\mathrm{P}_{2} \mathrm{O}_{5}, \mathrm{~K}_{2} \mathrm{O}, \mathrm{Ca}, \mathrm{Mg}, \mathrm{S}, \mathrm{B}, \mathrm{Fe}, \mathrm{Zn}, \mathrm{Cu}, \mathrm{Mn}$ and organic matter status. The soil fertility status maps were made using Arc-GIS 10.1 software. The observed data revealed that soil was grayish brown in colour and sub-angular blocky in structure. The sand, silt and clay content were $36.03 \pm 3.66 \%, 50.32 \pm 2.52 \%$ and $25.42 \pm 2.25 \%$, respectively and categorized as eight different classes of texture. The soil was acidic in $\mathrm{pH}(5.61 \pm 0.14)$. The available sulphur $(0.73 \pm 0.09 \mathrm{ppm})$ status was very low, whereas organic matter $(1.34 \pm 0.07 \%)$, available boron $(0.56 \pm 0.10 \mathrm{ppm})$, available zinc $(0.54 \pm 0.22 \mathrm{ppm})$ and available copper $(0.30 \pm 0.01 \mathrm{ppm})$ were low in status. The extractable potassium $(95.52 \pm 13.37 \mathrm{ppm})$ and extractable calcium $(1264.8 \pm 92.80 \mathrm{ppm})$ exhibited medium in status. In addition, available phosphorus (33.25 $\pm 6.97 \mathrm{ppm})$, available magnesium $(223.20 \pm 23.65 \mathrm{ppm})$ and available manganese $(20.50 \pm 2.43 \mathrm{ppm})$ were high in status. Furthermore, available iron $(55.80 \pm 8.89 \mathrm{ppm})$ status was very high. To improve the potentiality of crops (maize, rice, wheat etc.) for studied area, future research strategy should be made based on its soil fertility status.
\end{abstract}

Keywords: Nutrient management, research efficacy, soil fertility maps; and soil testing

Correct citation: Khadka, D., Lamichhane, S., Khan, S., Joshi, S., \& Pant, B.B. (2016). Assessment of soil fertility status of Agriculture Research Station, Belachapi, Dhanusha, Nepal. Journal of Maize Research and Development, 2(1): 43-57, doi: http://dx.doi.org/10.3126/jmrd.v2i1.16214 


\section{INTRODUCTION}

The sustainability of any system has become major concern now days. The evaluation of soil fertility is perhaps the most basic decision making tool in order to impose appropriate nutrient management strategies (Brady \& Weil, 2004). There are various techniques for soil fertility evaluation, among them soil testing is the most widely used in the world (Havlin et al., 2010). Soil testing assess the current fertility status and provides information regarding nutrient availability in soils which forms the basis for the fertilizer recommendations for maximizing crop yields and to maintain the adequate fertility in soils for longer period. The texture, structure, colour etc. are important soil physical parameters. Similarly, soil reaction $(\mathrm{pH})$, organic matter, macro and micronutrients etc. are also important soil chemical parameters. The physical and chemical tests provide information about the capacity of soil to supply mineral nutrients (Ganorkar \& Chinchmalatpure, 2013). Spatial variation across a field become great challenge for assesses soil fertility of an area. Describing the spatial variability of soil fertility across a field has been difficult until new technologies such as Global Positioning Systems (GPS) and Geographic Information Systems (GIS) were introduced. GIS is a powerful set of tools for collecting, storing, retrieving, transforming and displaying spatial data (Burrough \& McDonnell, 1998). Nepal Agricultural Research Council (NARC) was established to strengthen agriculture sector in the country through agriculture research. Agriculture Research Station, Belachapi, Dhanusha is an important wing among the research farms of NARC, in order to generate appropriate agriculture production technologies for central terai of Nepal. The research of different field crops (rice, wheat, maize, pulses etc.) and vegetables are being carried out from longer period of time in the farm. Studies related to the soil fertility status of Agriculture Research Station, Belachapi, Dhanusha are scant. Therefore, it is important to investigate the soil fertility status and it may provide valuable information relating crop research. Considering these facts, the present study was initiated with the objective to assess the soil fertility status of Agriculture Research Station, Belachapi, Dhanusha, Nepal.

\section{Study area}

\section{MATERIALS AND METHODS}

The study was carried out at Agriculture Research Station, Belachapi, Dhanusha, Nepal (Figure 1). The research farm is situated at the latitude $26^{\circ} 52^{\prime} 22.7^{\prime \prime} \mathrm{N}$ and longitude $85^{\circ} 56^{\prime} 54.5^{\prime} \mathrm{E}$ as well altitude $101 \mathrm{masl}$.

\section{Soil sampling}

The surface soil samples $(0-20 \mathrm{~cm}$ depth $)$ were collected from Agriculture Research Station, Belachapi during January 2015. Altogether soil samples were collected from the research farm by using soil sampling auger (Figure 2). The exact locations of the samples were recorded using a handheld GPS receiver. The random method based on the variability of the land was used to collect soil samples. 


\section{Laboratory analysis}

The collected soil samples were analyzed at Soil Science Division laboratory, Khumaltar. The different soil parameters tested as well as methods adopted to analyze is shown on the Table 1 .

\section{Statistical analysis}

Descriptive statistics (mean, range, standard deviation, standard error, coefficient of variation) of soil parameters were computed using the Minitab 17 package. Rating (very low, low, medium, high and very high) of determined values were based on Soil Science Division, Khumaltar. The coefficient of variation was ranked according to the procedure of (Aweto, 1982) where, $\mathrm{CV}<25 \%=$ low variation, $\mathrm{CV}>25 \leq 50 \%=$ moderate variation, $\mathrm{CV}>50 \%=$ high variation. Arc Map 10.1 with geostatistical analyst extension of Arc GIS software was used to prepare soil fertility maps while interpolation method employed was ordinary kriging with stable semi-variogram. Similarly, the nutrient index was also determined by the formula given by Ramamoorthy and Bajaj (1969).

\section{Nutrient index (N.I.) $=\left(\mathbf{N}_{L} \times 1+N_{M} \times 2+N_{H} \times 3\right) / N_{T}$}

Where, $\mathrm{N}_{L}, \mathrm{~N}_{M}$ and $\mathrm{N}_{\mathrm{H}}$ indicates number of samples falling in low, medium and high classes of nutrient status, respectively and $\mathrm{N}_{\mathrm{T}}$ means total number of samples analyzed for a given area. Similarly, interpretation was done as value given by Ramamoorthy shown on the Table 2.

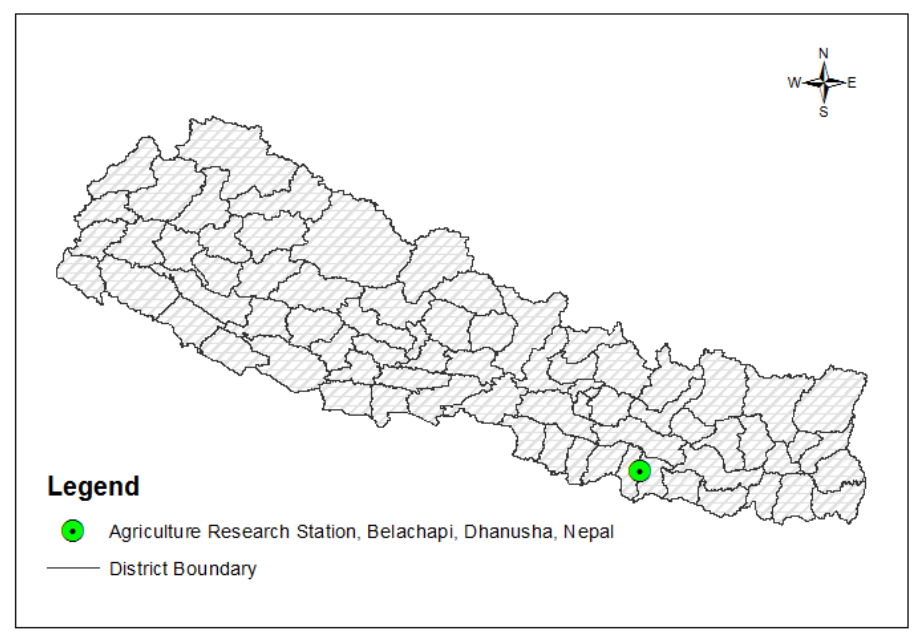

Figure 1. Location Map of Agriculture Research Station, Belachapi, Dhanusha, Nepal 
DOI: http://dx.doi.org/10.3126/jmrd.v2i1.16214

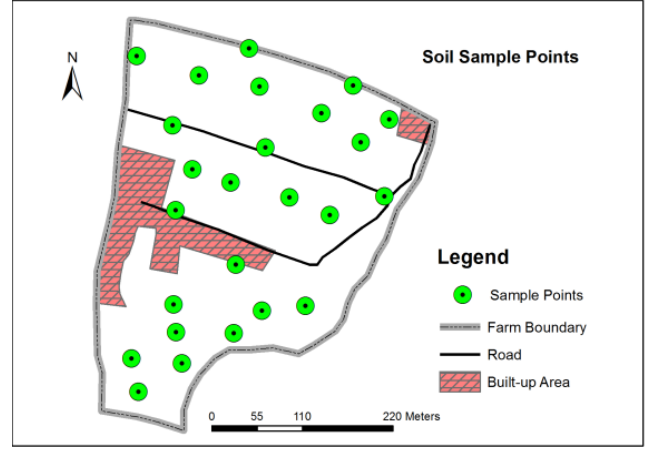

Figure 2. Distribution of soil sample points during soil sampling

Table 1. Parameters and methods adopted for the laboratory analysis at Soil Science Division, Khumaltar

\begin{tabular}{llll}
\hline S.N. & Parameters & Unit & Methods \\
\hline 1. & Physical & & \\
& Soil texture & & Hydrometer (Bouyoucos, 1927) \\
Soil colour & Munshell-colour chart
\end{tabular}

Table 2. Rating Chart of Nutrient index

\begin{tabular}{lll}
\hline S.N. & Nutrient Index & Value \\
\hline 1. & High & $>2.33$ \\
2. & Low & $<1.67$ \\
3. & Medium & $1.67-2.33$ \\
\hline
\end{tabular}

\section{RESULTS AND DISCUSSION}

In the study area its soil fertility status with respect to texture, colour, structure, $\mathrm{pH}$, organic matter, primary nutrients, secondary nutrients and micronutrients such as $\mathrm{B}, \mathrm{Fe}, \mathrm{Zn}, \mathrm{Cu}$, and $\mathrm{Mn}$, was assessed and the results obtained are presented and discussed in the following headings. 


\section{Soil texture}

Soil texture affects the soil sustainability. The sand, silt and clay are the three components of soil texture. It affects absorption of nutrients, microbial activities, the infiltration and retention of water, soil aeration, tillage and irrigation practices (Gupta, 2004). The \% sand of soil samples were ranged from 8.2 to $67.6 \%$ with the mean value of $36.03 \%$ and that of $\%$ silt were 12.8 to $68.8 \%$ with a mean of $50.32 \%$ while the range of $\%$ clay were 3.6 to $39.8 \%$ with a mean of $25.42 \%$ (Table 3 ). The coefficients of variation between the soil samples were $75.53 \%$, $25.04 \%$ and $44.3 \%$ for sand, silt and clay contents, respectively.

Table 3. Soil separates status of Agriculture Research Station, Belachapi, Dhanusha, Nepal

\begin{tabular}{lccc}
\hline \multirow{2}{*}{ Descriptive Statistics } & \multicolumn{3}{c}{ Soil separates (\%) } \\
\cline { 2 - 4 } & Sand & Silt & Clay \\
\hline Mean & 36.03 & 50.32 & 25.42 \\
Standard Deviation & 18.32 & 12.60 & 11.26 \\
Standard Error & 3.66 & 2.52 & 2.25 \\
Minimum & 8.2 & 12.8 & 3.6 \\
Maximum & 67.6 & 68.8 & 39.8 \\
CV\% & 75.53 & 25.04 & 44.3 \\
\hline
\end{tabular}

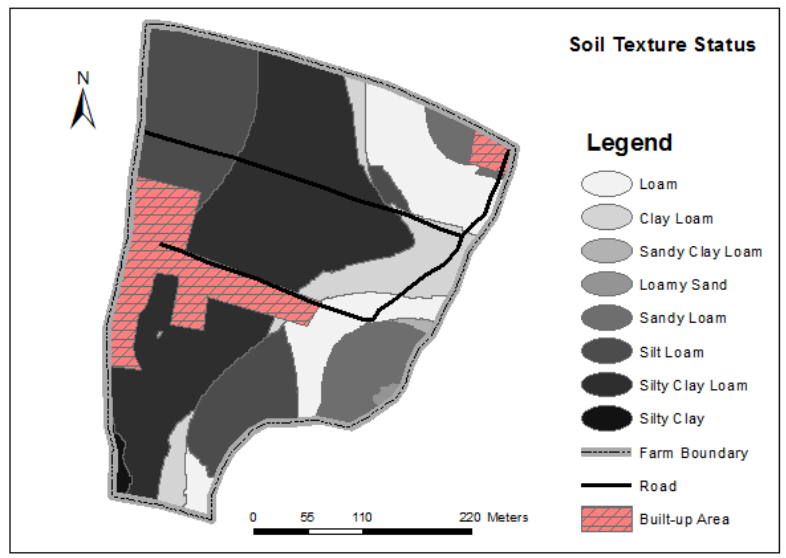

Figure 3. Soil texture status of Agriculture Research Station, Belachapi, Dhanusha, Nepal

\section{Soil colour}

Soil color reflects on the transformation and translocation occurred in the soil due to chemical, biological and physical attributes (Ponnamperuma \& Deturck, 1993). It shows water drainage, aeration and organic matter content in soil. In the majority of the study area, grayish brown (10YR 6/1) colour was observed. 


\section{Soil structure}

Soil structure refers to the pattern of spatial arrangement of soil particles in a soil mass (Brady \& Weil, 2004). In the majority of the area, sub angular blocky structure was observed.

\section{Soil pH}

Soil $\mathrm{pH}$ is important chemical parameter of soil that affects nutrient availability (Brady and Weil, 2004). The $\mathrm{pH}$ of soil was varied from 4.58 to 7.33 with a mean value of 5.61 (Table 4). This indicates moderately acidic soil $\mathrm{pH}$ (Figure 4). The availability of various nutrients for plants (rice, wheat, maize, vegetables etc.) may be reduced. Therefore, periodically agricultural lime incorporation is imperative for improvement of soil $\mathrm{pH}$. The soil $\mathrm{pH}$ showed low variability $(12.41 \%)$ among the soil samples.

Table 4. Soil fertility status of Agriculture Research Station, Belachapi, Dhanusha, Nepal

\begin{tabular}{llllll}
\hline \multirow{2}{*}{ Descriptive Statistics } & \multicolumn{5}{c}{ Soil Fertility Parameters (ppm) } \\
\cline { 2 - 6 } & $\mathrm{pH}$ & $\mathrm{OM}$ & $\mathrm{N}$ & $\mathrm{P}_{2} \mathrm{O}_{5}$ & $\mathrm{~K}_{2} \mathrm{O}$ \\
\hline Mean & 5.61 & 1.34 & 0.08 & 33.25 & 95.52 \\
Standard Deviation & 0.70 & 0.36 & 0.01 & 34.86 & 66.87 \\
Standard Error & 0.14 & 0.073 & 0.002 & 6.97 & 13.37 \\
Minimum & 4.58 & 0.19 & 0.04 & 0.78 & 21.6 \\
Maximum & 7.33 & 1.92 & 0.09 & 145.51 & 369.6 \\
CV\% & 12.41 & 27.15 & 13.56 & 104.73 & 70.01 \\
\hline
\end{tabular}

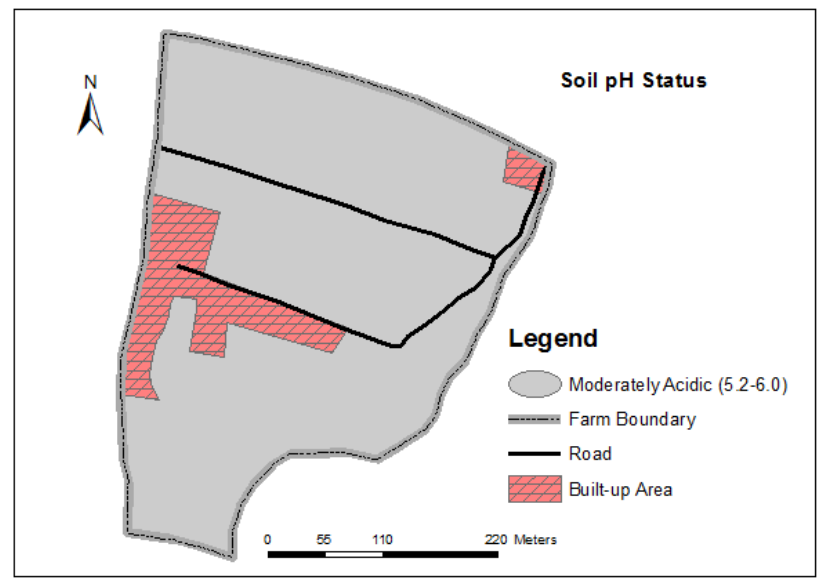

Figure 4. Soil pH status of Agriculture Research Station, Belachapi, Dhanusha, Nepal

\section{Organic matter}

Organic matter is important source of plant essential nutrients after their decomposition by microorganisms. It supplies plant nutrient, improve the soil structure, water infiltration and retention, feeds soil micro-flora and fauna, and the retention and cycling of applied fertilizer (Johnston, 2007). The organic matter content was varied from 0.19 to $1.92 \%$ with a mean value of $1.34 \%$ (Table 4). It indicates that the organic matter content was low (Figure 5; Table 7). The 
plants don't have tolerance capacity against any kinds of stressed conditions. Therefore, incorporation of organic matter adding materials is imperative for organic matter improvement of soils. Organic matter showed moderate variability $(27.15 \%)$ among the soil samples.

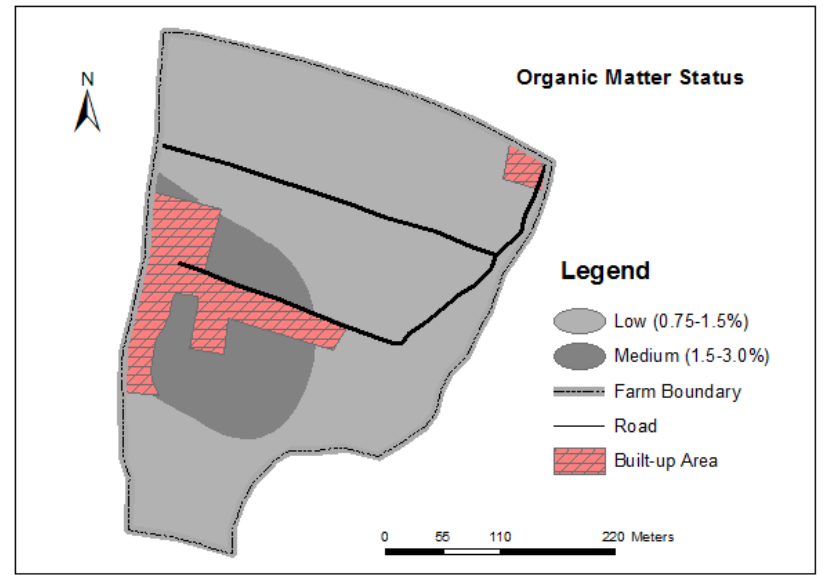

Figure 5. Organic matter status of Agriculture Research Station, Belachapi, Dhanusha, Nepal

\section{Total nitrogen}

Nitrogen is taken up by plants in greatest quantity next to carbon, oxygen and hydrogen, but in the tropics for crop production it is one of the most deficient elements (Mesfin, 1998). The total nitrogen content was ranged from 0.04 to $0.09 \%$ with a mean value of $0.08 \%$ (Table 4). This indicates medium content of total nitrogen (Figure 6; Table 7). The nitrogen content is not satisfactory. Therefore, regularly nitrogen adding organic and inorganic materials should be incorporated to make nitrogen balanced in soils. Low variability (13.56\%) in total nitrogen was observed among the sampled soils.

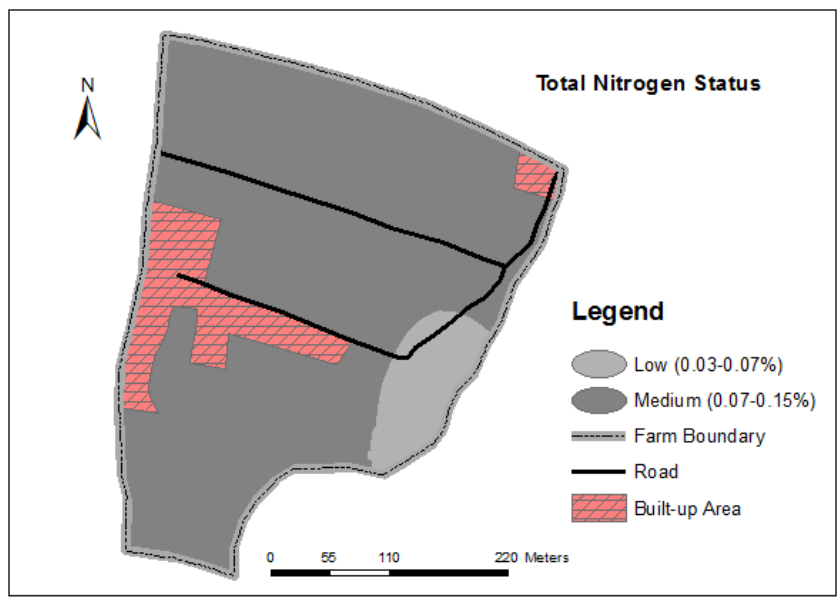

Figure 6. Total nitrogen status of Agriculture Research Station, Belachapi, Dhanusha, Nepal 


\section{Available phosphorus}

Phosphorus is the master key to agriculture. The growth of both cultivated and uncultivated plants is limited by availability of $\mathrm{P}$ in the soils (Foth and Ellis, 1997). The available phosphorus $\left(\mathrm{P}_{2} \mathrm{O}_{5}\right)$ was ranged from 0.78 to $145.51 \mathrm{ppm}$ with a mean value of $33.25 \mathrm{ppm}$ (Table 4). This showed high status of available phosphorus (Figure 7; Table 7). Available phosphorus showed high variability (104.73\%) among the tested soil samples.

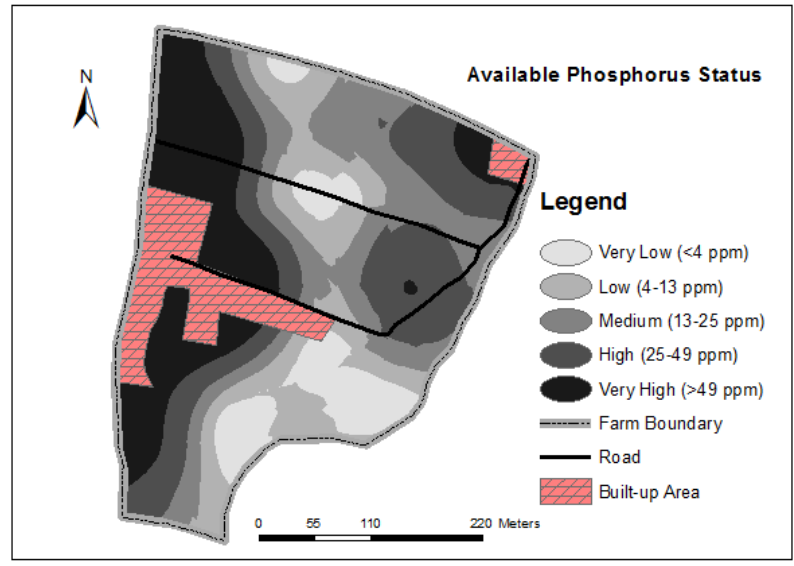

Figure 7. Available phosphorus status of Agriculture Research Station, Belachapi, Dhanusha, Nepal

\section{Extractable potassium}

Next to $\mathrm{N}$ and $\mathrm{P}$, Potassium $(\mathrm{K})$ is the third most important essential element that limit plant productivity. The extractable potassium $\left(\mathrm{K}_{2} \mathrm{O}\right)$ content was ranged from 21.6 to $369.6 \mathrm{ppm}$ with a mean value of $95.2 \mathrm{ppm}$. This suggests medium status of extractable potassium (Figure 8; Table 7). High variability $(70.01 \%)$ in extractable potassium was determined among the soil samples.

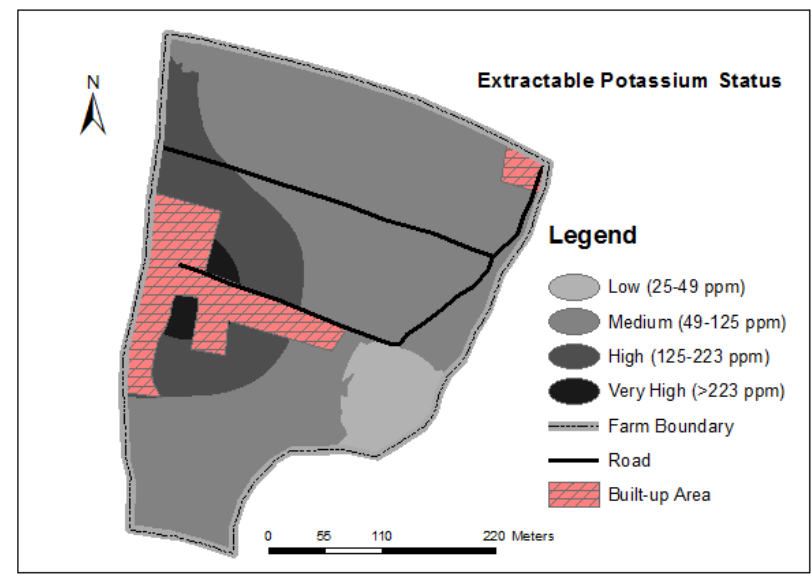

Figure 8. Extractable potassium status of Agriculture Research Station, Belachapi, Dhanusha, Nepal 
Journal of Maize Research and Development (2016) 2 (1): 43-57

ISSN: 2467-9291 (Print), 2467-9305 (Online)

DOI: http://dx.doi.org/10.3126/jmrd.v2i1.16214

Table 5. Soil fertility status of Agriculture Research Station, Belachapi, Dhanusha, Nepal

\begin{tabular}{lllll}
\hline \multirow{2}{*}{ Descriptive Statistics } & \multicolumn{4}{c}{ Soil Fertility Parameters (ppm) } \\
\cline { 2 - 5 } & $\mathrm{Ca}$ & $\mathrm{Mg}$ & $\mathrm{S}$ & $\mathrm{B}$ \\
\hline Mean & 1264.80 & 223.20 & 0.73 & 0.56 \\
Standard Deviation & 463.98 & 118.24 & 0.44 & 0.52 \\
Standard Error & 92.80 & 23.65 & 0.088 & 0.10 \\
Minimum & 180 & 12 & 0.29 & 0.15 \\
Maximum & 2080 & 432 & 1.81 & 2.61 \\
CV\% & 36.7 & 53.0 & 59.7 & 91.9 \\
\hline
\end{tabular}

\section{Extractable calcium}

Calcium is a secondary nutrient important for cell division in plants. The calcium content was ranged from 180 to $2080 \mathrm{ppm}$ with a mean value of $1264.80 \mathrm{ppm}$ (Table 5). In overall, medium status of extractable calcium was observed (Figure 9; Table 7). Moderate variability $(36.7 \%)$ in extractable calcium was observed among the soil samples.

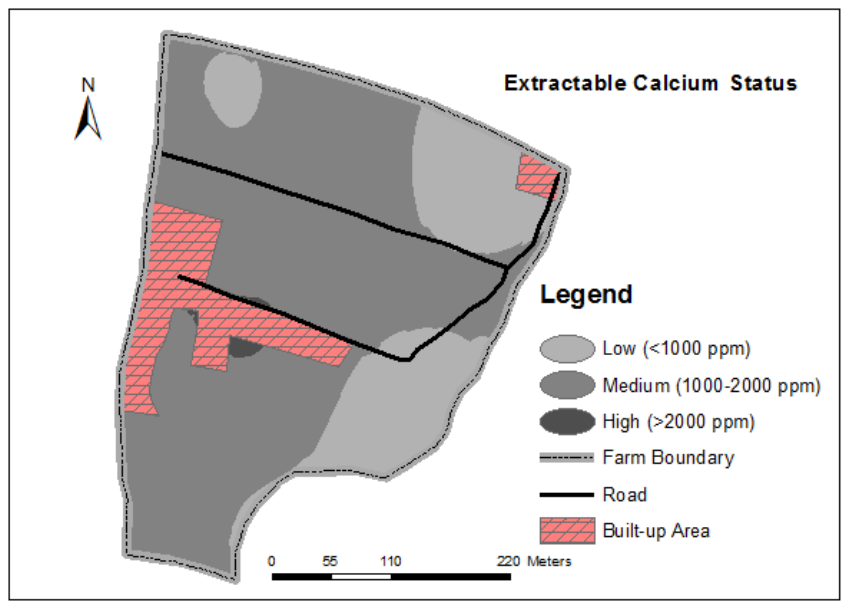

Figure 9. Extractable calcium status of Agriculture Research Station, Belachapi, Dhanusha, Nepal

\section{Extractable magnesium}

Magnesium is a water soluble cation necessary for chlorophyll pigment in green plants (Mahajan \& Billore, 2014). The magnesium content was ranged from 12 to 432 ppm with a mean value of $223.20 \mathrm{ppm}$ (Table 5). This revealed high content of extractable magnesium (Figure 10; Table 7). The variation (53\%) in the extractable magnesium of the observed samples is high. 
Journal of Maize Research and Development (2016) 2 (1): 43-57

ISSN: 2467-9291 (Print), 2467-9305 (Online)

DOI: http://dx.doi.org/10.3126/jmrd.v2i1.16214

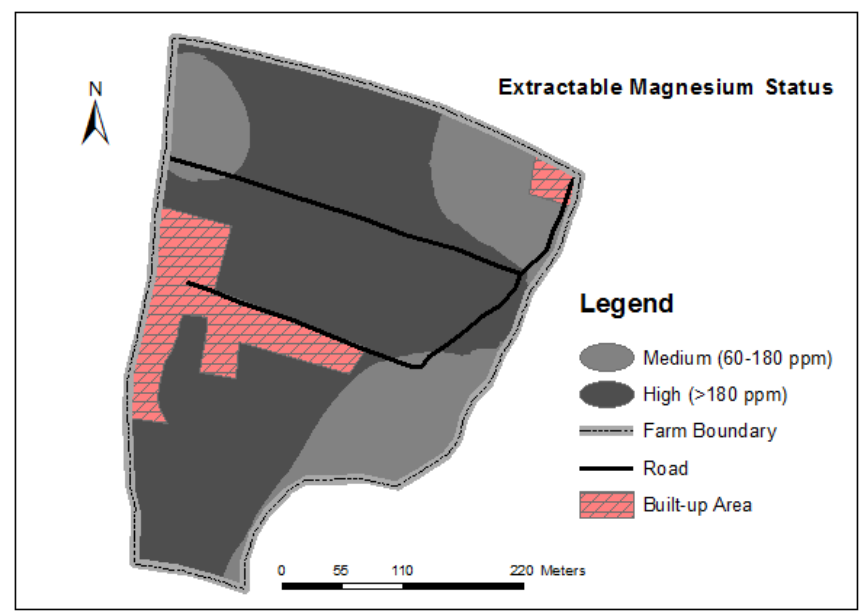

Figure 10. Extractable magnesium status of Agriculture Research Station, Belachapi, Dhanusha, Available sulphur

Nepal

Sulphur is required for synthesis of S-containing amino acids cystine, methionine and cysteine, and these are essential components of protein that comprise about $90 \%$ of the total $\mathrm{S}$ in plants (Havlin et al., 2010). The available sulphur was varied from 0.29 to $1.81 \mathrm{ppm}$ with a mean value of $0.73 \mathrm{ppm}$ (Table 5). In overall, available sulphur was very low in status (Figure 11; Table 7). Therefore, regularly sulphur adding organic and inorganic materials should be incorporate to reduce sulphur mining problem in soils. Organic matter improvement is also one option for enhancing availability of available sulphur. Available sulphur showed high variability $(59.7 \%)$ in the soil samples.

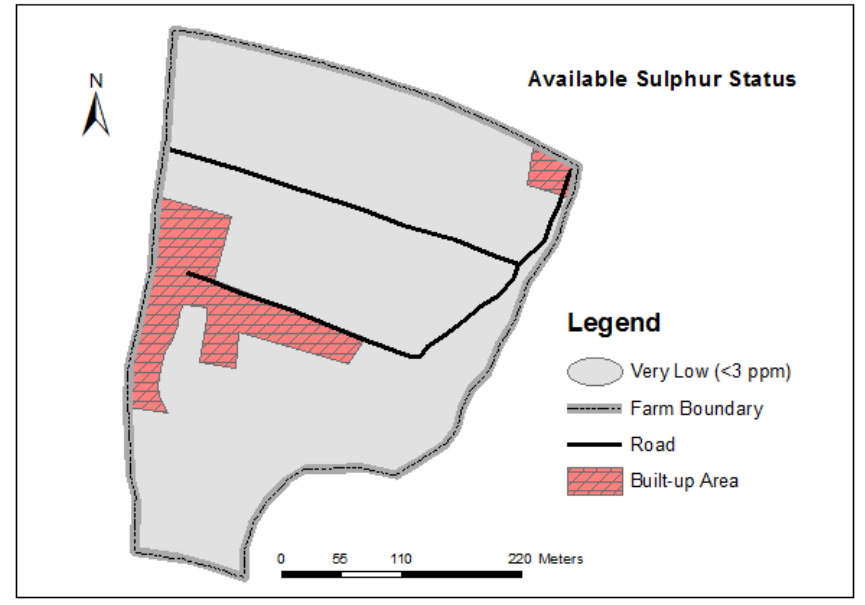

Figure 11. Available sulphur status of Agriculture Research Station, Belachapi, Dhanusha, Nepal

\section{Available boron}

Boron is required by plants for their cell wall structural integrity (Havlin et al., 2010). The available boron content was ranged from 0.15 to $2.61 \mathrm{ppm}$ with a mean value of $0.56 \mathrm{ppm}$ (Table 5). This indicates low content of available boron (Figure 12; Table 7). Therefore, regularly boron adding organic and inorganic materials should be incorporate to maintain boron 
adequate in soils. High variability $(91.9 \%)$ in available boron was observed among the soil samples.

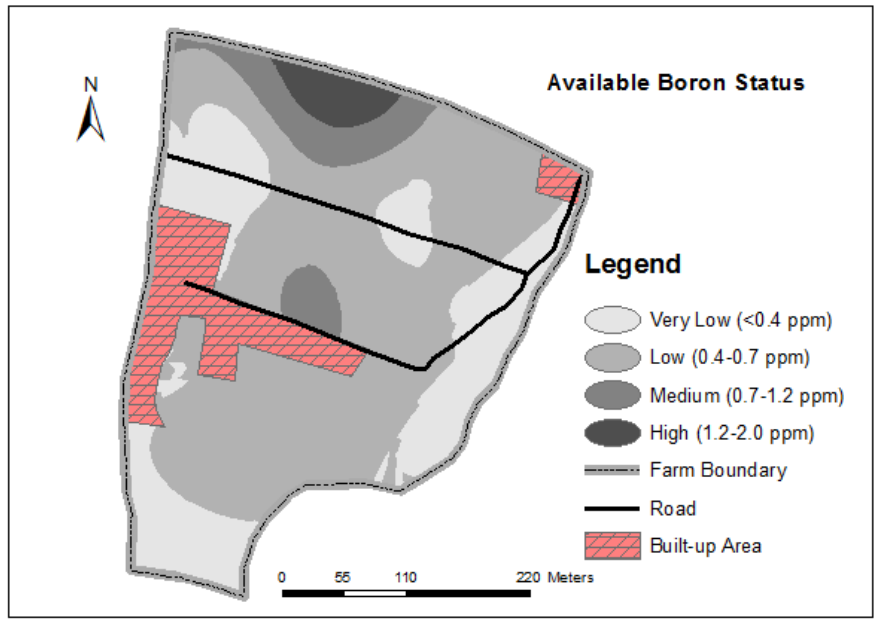

Figure 12. Available boron status of Agriculture Research Station, Belachapi, Dhanusha, Nepal

\section{Available iron}

Iron is an essential micronutrient for almost all living organisms because of it plays critical role in metabolic processes such as DNA synthesis, respiration, and photosynthesis (Rout \& Sahoo, 2015). The available iron content was ranged from 5.56 to 160.7 ppm with a mean value of $55.80 \mathrm{ppm}$ (Table 6). In overall, available iron status was high (Figure 13; Table 7). There may have high possibility for stress of iron toxicity as well deficiency of antagonistic elements in plants. Therefore, nutrients like potassium; phosphorus etc. should be applied in adequate amount for reducing iron toxicity stress in plants. Available iron showed high variability (79.7\%) among the soil samples.

Table 6. Soil fertility status of Agriculture Research Station, Belachapi, Dhanusha, Nepal

\begin{tabular}{lllcl}
\hline \multirow{2}{*}{ Descriptive Statistics } & \multicolumn{4}{c}{ Soil Fertility Parameters } \\
\cline { 2 - 5 } & Fe & Zn & Cu & Mn \\
\cline { 2 - 5 } & \multicolumn{4}{c}{ ppm } \\
\hline Mean & 55.80 & 0.54 & 0.30 & 20.50 \\
Standard Deviation & 44.45 & 1.08 & 0.06 & 12.14 \\
Standard Error & 8.89 & 0.22 & 0.01 & 2.43 \\
Minimum & 5.56 & 0.08 & 0.12 & 5.62 \\
Maximum & 160.7 & 5.58 & 0.4 & 47.5 \\
CV\% & 79.7 & 199.7 & 21.4 & 59.3 \\
\hline
\end{tabular}




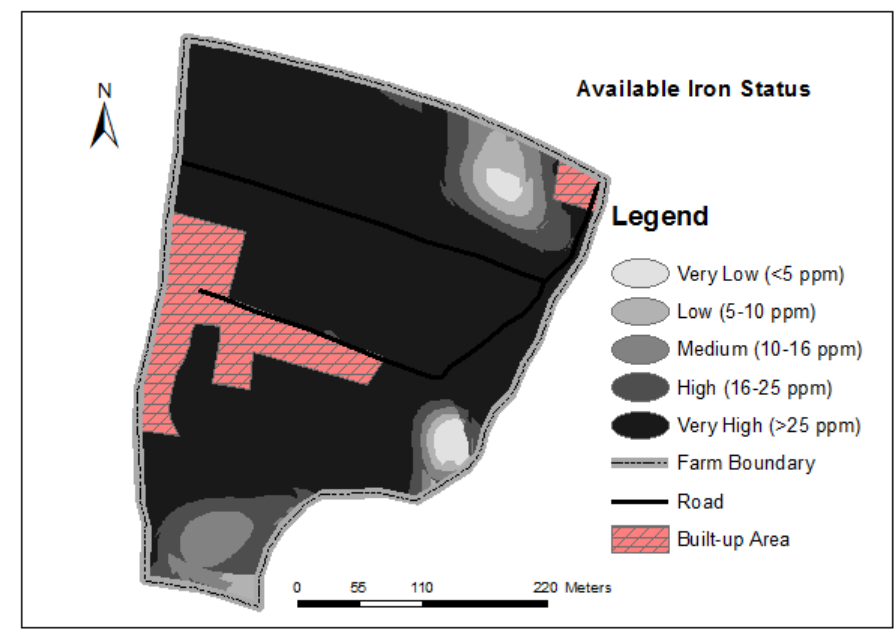

Figure 13. Available iron status of Agriculture Research Station, Belachapi, Dhanusha, Nepal

\section{Available zinc}

Zinc is essential for several biochemical processes in plants, such as cytochrome and nucleotide synthesis, auxin metabolism, chlorophyll production, enzyme activation, and the maintenance of membrane integrity (Havlin et al., 2010). The available zinc content was ranged from 0.08 to $5.58 \mathrm{ppm}$ with a mean value of $0.54 \mathrm{ppm}$ (Table 6). This indicates low status of available zinc (Figure 14; Table 7). There may have high possibility of zinc deficiency symptoms like white bud in maize, khaira disease in rice etc. Therefore, different organic and inorganic sources of zinc should be applied in the field regularly to reduce zinc stress in plants. The available zinc showed high variability (199.7\%) among the soil samples.

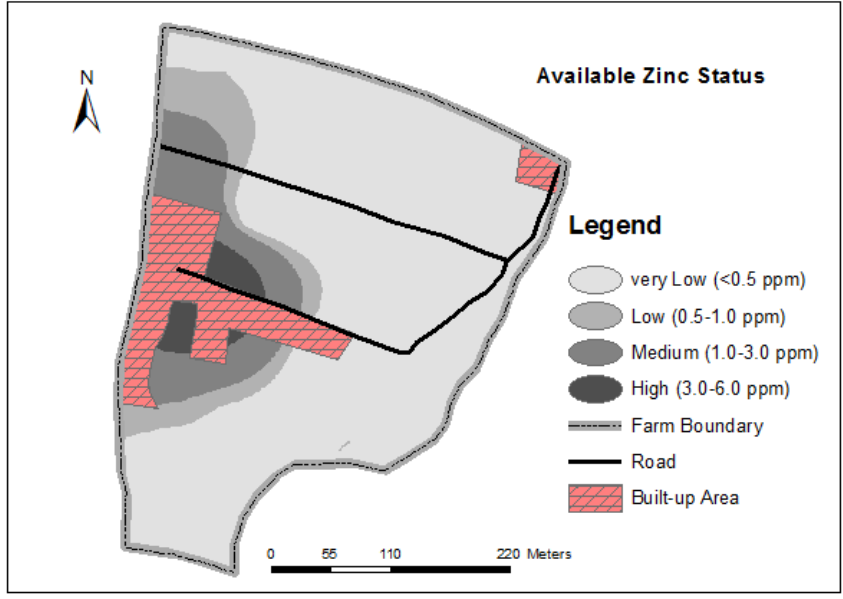

Figure 14. Available zinc status of Agriculture Research Station, Belachapi, Dhanusha, Nepal

\section{Available copper}

Copper is also important micronutrient for plants, and required for lignin synthesis and acts as a constituent of ascorbic acid, oxidase, phenolase and plastocyanin (Havlin et al., 2010). The available copper content was varied from 0.12 to $0.4 \mathrm{ppm}$ with the mean value of $0.30 \mathrm{ppm}$ (Table 6). This indicates low status of available copper (Figure 15; Table 7). Therefore, proper 
copper management strategy should be adopted to make copper balanced in soils. Low variability $(21.4 \%)$ in available copper was recorded among the soil samples.

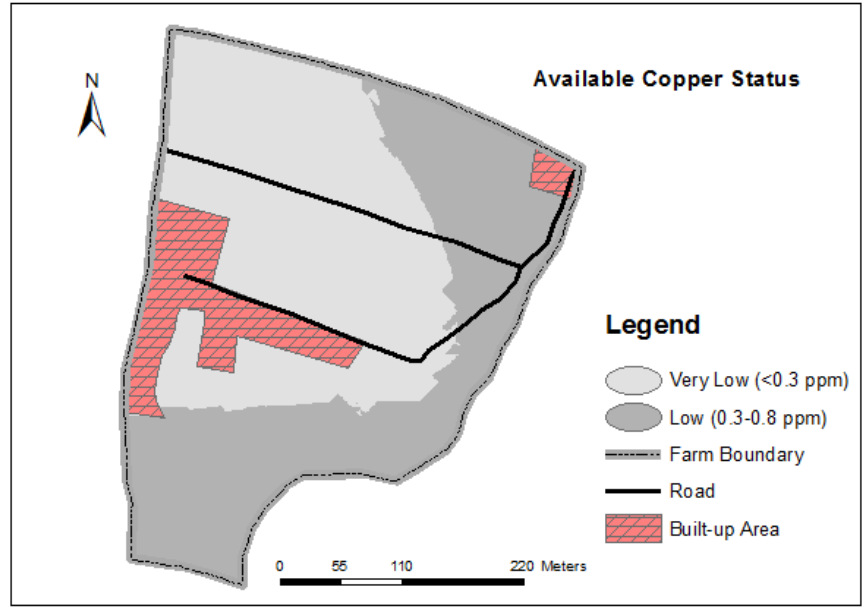

Figure 15. Available copper status of Agriculture Research Station, Belachapi, Dhanusha, Nepal

\section{Available manganese}

Manganese plays an important role in oxidation and reduction processes in plants (Mousavi et al., 2011).The available manganese content was ranged from 5.62 to $47.5 \mathrm{ppm}$ with the mean value of $20.50 \mathrm{ppm}$ (Table 6). This indicates high status of available manganese (Figure 16; Table 7). The available manganese showed high variability (59.3\%) among the studied soil samples.

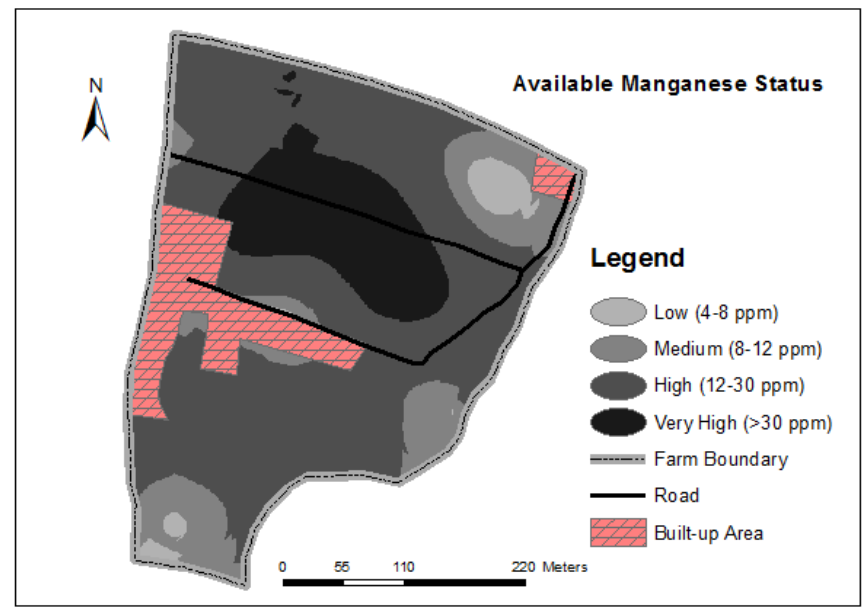

Figure 16. Available manganese status of Agriculture Research Station, Belachapi, Dhanusha, Nepal 
Journal of Maize Research and Development (2016) 2 (1): 43-57

ISSN: 2467-9291 (Print), 2467-9305 (Online)

DOI: http://dx.doi.org/10.3126/jmrd.v2i1.16214

Table 7. Nutrient indices of studied parameters of Agriculture Research Station, Belachapi, Dhanusha, Nepal

\begin{tabular}{|c|c|c|c|c|c|c|c|c|}
\hline \multirow[b]{2}{*}{ S.N. } & \multirow[b]{2}{*}{ Parameters } & \multicolumn{5}{|c|}{$\%$ distribution of samples } & \multirow[b]{2}{*}{$\begin{array}{c}\begin{array}{c}\text { Nutrient } \\
\text { index }\end{array} \\
\end{array}$} & \multirow[b]{2}{*}{ Remarks } \\
\hline & & $\begin{array}{l}\text { Very } \\
\text { Low }\end{array}$ & Low & Medium & High & $\begin{array}{l}\text { Very } \\
\text { High }\end{array}$ & & \\
\hline 1. & $\mathrm{OM}$ & 4 & 64 & 32 & - & - & 1.32 & Low \\
\hline 2. & $\mathrm{~N}$ & - & 40 & 60 & - & - & 1.6 & Low \\
\hline 3. & $\mathrm{P}_{2} \mathrm{O}_{5}$ & 20 & 8 & 20 & 28 & 24 & 2.24 & Medium \\
\hline 4. & $\mathrm{~K}_{2} \mathrm{O}$ & 4 & 12 & 68 & 12 & 4 & 2.0 & Medium \\
\hline 5. & $\mathrm{Ca}$ & - & 32 & 64 & 4 & - & 1.4 & Low \\
\hline 6. & $\mathrm{Mg}$ & - & 8 & 36 & 56 & - & 2.48 & High \\
\hline 7. & S & 100 & - & - & - & - & 1.0 & Low \\
\hline 8. & B & 52 & 24 & 16 & 4 & 4 & 1.32 & Low \\
\hline 9. & $\mathrm{Fe}$ & - & 12 & 4 & 16 & 68 & 2.72 & High \\
\hline 10. & $\mathrm{Zn}$ & 84 & 8 & 4 & 4 & - & 1.12 & Low \\
\hline 11. & $\mathrm{Cu}$ & 36 & 64 & - & - & - & 1.0 & Low \\
\hline 12. & $\mathrm{Mn}$ & - & 12 & 20 & 40 & 28 & 2.56 & High \\
\hline
\end{tabular}

\section{CONCLUSION}

Overall, the colour of soil was grayish brown and structure was sub-angular blocky. Soils were acidic in reaction and it is advisable to apply agricultural lime periodically for its amelioration. The sulphur status was very low. The organic matter, boron, zinc and copper status were low. The nitrogen, potassium and calcium status were medium. The phosphorus, magnesium and manganese status were high. The iron was very high in status. The crops (maize, rice, wheat etc.) may suffer from deficiency of low and toxicity of very high plant available nutrients. Thus, proper nutrient management strategy should be adopted especially for these nutrients. Considering the low status of soil organic matter, the practices like manure or compost incorporation, crop residue retention, green manuring etc. can be suggested for its improvement. From this study, it can be concluded that for enhancing efficacy of the agricultural research (maize, rice, wheat etc.) future research strategy should be built based on the soil fertility status of the farm.

\section{ACKNOWLEDGEMENTS}

The authors would like to acknowledge Nepal Agricultural Research Council for funding this research. We are very much thankful to Agriculture Research Station, Belachapi, for their cooperation. Similarly, support of the Soil Science Division, Khumaltar for providing laboratory facilities to analyze the soil samples and preparation of soil fertility maps as well as other technical support is highly acclaimed.

\section{REFERENCES}

Aweto, A.O. (1982). Variability of upper slope soils developed under sandstones in Southwestern Nigeria. Geographic Journal, 25, 27-37.

Berger, K. C, \& Truog, E. (1939). Boron determination in soils and plants. Industrial and Engineering Chemistry, 11, 540 - 545. 
Bouyoucos, G. J. (1962). Hydrometer method improved for making particle-size analysis of soils. Agronomy Journal, 53, $464-465$.

Brady, N.C., \& Weil, R.R. (2002). The nature and properties of soils (13 ${ }^{\text {th }}$ edition). Pearson Education, New Jersey.

Bremner, J.M., \& Mulvaney, C.S. (1982). Nitrogen total. In: Page, A.L. (editor) Methods of soil analysis. Agron. No. 9, Part 2: Chemical and microbiological properties. $2^{\text {nd }}$ edition. Am. Soc. Agron., Madison, WI, USA, 595- 624.

Burrough, P.A., \& McDonnell, R. A. (1998). Principle of geographic information systems. Oxford: Oxford University Press.

El Mahi,Y., Ibrahim, I.S., AbdelMajid, H.M., \& Eltilib, A.M. (1987). A simple method for determination of calcium and magnesium carbonate in soils. Soil Science Society of American Journal, 51, 1152-1155.

Foth, H.D., \& Ellis, B.G. (1997). Soil fertility (2 $2^{\text {nd }}$ edition). LLC., USA: Lewis CRC Press, 290p.

Ganorkar, R.P., \& Chinchmalatpure, P.G. (2013). Physicochemical assessment of soil in Rajura Bazar in Amravati district of Maharastra (India). International Journal of Chemical, Environmental and Pharmaceutical Research, 4(2\&3), 46-49.

Gupta, P.K. (2004): Soil, plant, water and fertilizer analysis. Shyam Printing Press, Agrobios, India, 38p.

Havlin, H.L., Beaton, J.D., Tisdale, S. L., \& Nelson, W. L. (2010). Soil Fertility and Fertilizersan introduction to nutrient management ( $7^{\text {th }}$ edition). PHI Learning Private Limited, New Delhi.

Jackson, M. L. (1973). Soil chemical analysis. Prentice Hall of India Pvt. Ltd., New Delhi.

Johnston A.E. (2007). Soil organic matter, effects on soil and crop. Soil use and management, 2(3), 97-105.

Lindsay, W. L., \& Norvell, W. A. (1978). Development of a DTPA soil test for zinc, iron, manganese, and copper. Soil Science Society of American Journal, 42, 421 - 428.

Mahajan, S., \& Billore, D. (2014). Assessment of physico-chemical characteristics of the soil of Nagchoon pond Khandwa, MP, India. Research Journal of Chemical Science, 4(1), 2630.

Mesfin, A. (1998). Nature and management of Ethiopian soils. Ethiopia: Alemaya University of Agriculture, 272p.

Mousavi, S.R., Shahsavari, M., \& Rezaei, M. (2011). A general overview of manganese (Mn) importance for crops production. Australian Journal of Basic and Applied Sciences, 5(9), 1799-1803.

Olsen, S. R., Cole, C. V., Watanabe, F. S., \& Dean, L. A. (1954). Estimation of available phosphorus in soils by extraction with sodium bicarbonate. US. Department of Agriculture Circle, 9, 39.

Ramamurthy, B., \& Bajaj, J.C. (1969). Available nitrogen, phosphorus and potassium status of Indian soils. Fertilizer News, 14, 25-36.

Rout, G.R. \& Sahoo, S. 2015. Role of iron in plant growth and metabolism. Review of Agriculture Science, 3, 1-24.

Verma, B. C. (1977). An improved Turbidimetric procedure for the determination of sulphate in plants and soils. Talanta, 24, $49-50$.

Walkley, A.J., \& Black, I.A. (1934). Estimation of soil organic carbon by the chromic acid titration method. Soil Science, 37, 29-38. 